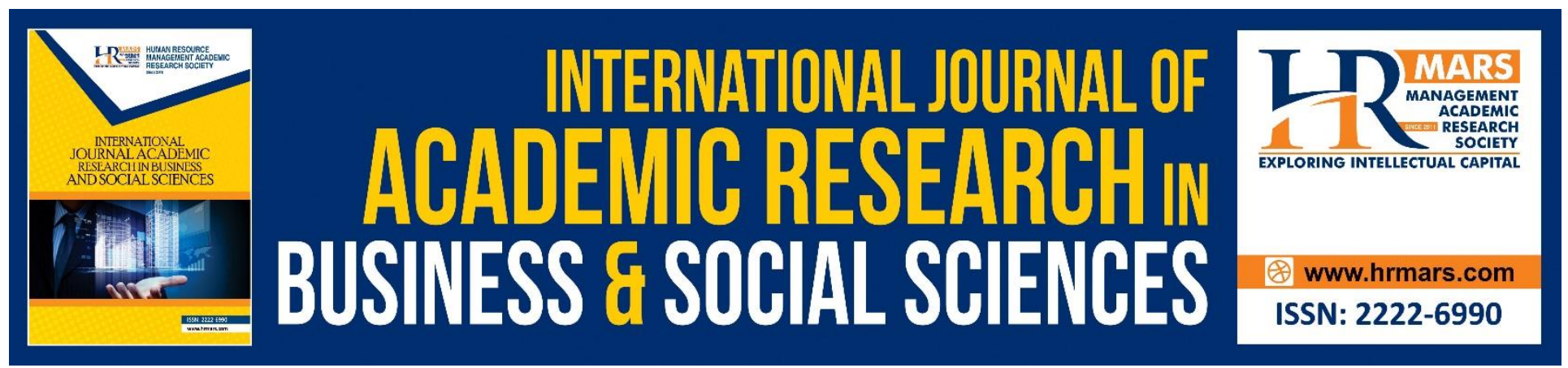

\title{
Challenges Facing Educators of Social Studies in Exploring the Values of Citizenship amongst Students of Primary Schools in Ajloun
}

Najihah Abd Wahid, Khitam Al-Smadi, Anas Mohd Yunus, and Samer Al-Irsan

To Link this Article: http://dx.doi.org/10.6007/IJARBSS/v9-i6/5952 DOI: 10.6007/IJARBSS/v9-i6/5952

Received: 02 March 2019, Revised: 30 April 2019, Accepted: 19 May 2019

Published Online: 12 June 2019

In-Text Citation: (Wahid, Al-Smadi, Yunus, \& Al-Irsan, 2019)

To Cite this Article: Wahid, N. A., Al-Smadi, K., Yunus, A. M., \& Al-Irsan, S. (2019). Explore Challenges that Face Teachers of Citizenship Education in Primary Schools Education Directorate in Ajloun. International Journal of Academic Research Business and Social Sciences, 9(6), 337-357.

Copyright: (C) 2019 The Author(s)

Published by Human Resource Management Academic Research Society (www.hrmars.com)

This article is published under the Creative Commons Attribution (CC BY 4.0) license. Anyone may reproduce, distribute, translate and create derivative works of this article (for both commercial and non-commercial purposes), subject to full attribution to the original publication and authors. The full terms of this license may be seen at: $\underline{\text { http://creativecommons.org/licences/by/4.0/legalcode }}$

Vol. 9, No. 6, 2019, Pg. 337 - 357

http://hrmars.com/index.php/pages/detail/IJARBSS

JOURNAL HOMEPAGE

Full Terms \& Conditions of access and use can be found at http://hrmars.com/index.php/pages/detail/publication-ethics 


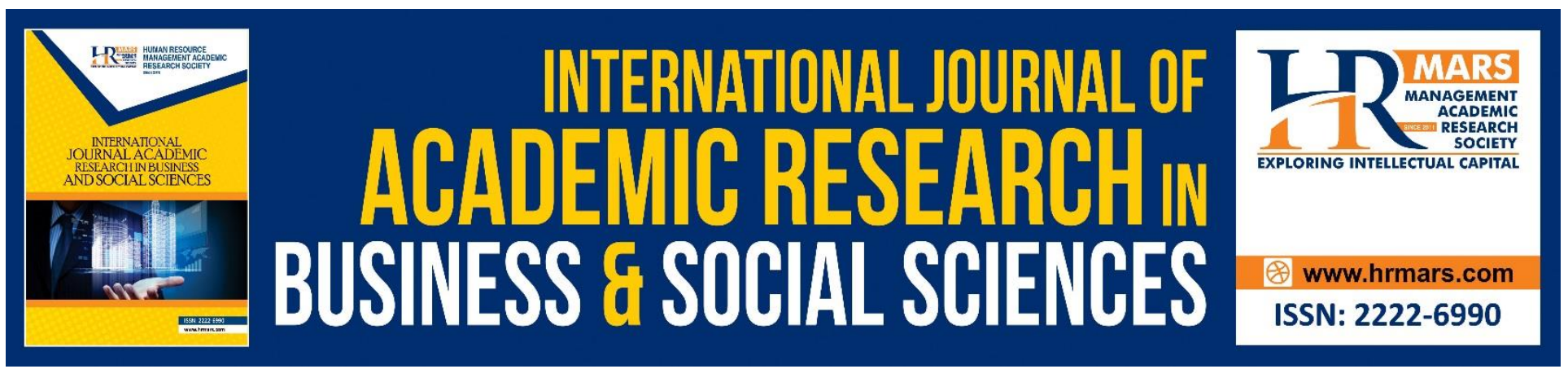

\section{Challenges Facing Educators of Social Studies in Exploring the Values of Citizenship amongst Students of Primary Schools in Ajloun}

Najihah Abd Wahid ${ }^{1, a}$, Khitam Al-Smadi², Anas Mohd Yunus ${ }^{3}$, and Samer Al-Irsan ${ }^{4}$

${ }^{1}$ Research Institute for Islamic products \& Civilization (INSPIRE), UniSZA, Malaysia

${ }^{2}$ Faculty of Islamic Contemporary studies, UniSZA, Trg. Malaysia, Ketam Smadi@yahoo.com

${ }^{3}$ Faculty of Islamic Contemporary studies, UniSZA, Trg. Malaysia, anassmhasnah@gmail.com

${ }^{4}$ Educational Psychology, University of Hail, Kingdom of Saudi Arabia, dr.samerersan@gmail.com

aEmail: anajihah@unisza.edu.my

\section{Abstract}

This study presents the challenges that are facing the teachers of the social studies in exploring the values of the citizenship of the students in the primary schools in Ajloun as viewed by the educators. The study uses a descriptive method with a questionnaire distributed to a sample of 150 teachers serving in the Directorate of Education of Ajloun Governorate. A total of 94 valid responses (about $63 \%)$ were collected and examined statistically for further analysis. The questionnaire includes seven areas: objectives, methods, and educational activities, methods of teaching and presentation of content, use of learning resources, classroom management, and classroom interaction, enhancing skills, values, and trends, and finally assessment methods. The study found that the most important challenges facing teachers in teaching the values of citizenship to students are not directly attached to the particulars related to teaching concepts of citizenship. The study indicated difficulty in achieving mutual interaction between students themselves and between students and teachers. The results also showed that there were no statistically significant differences in respondents' estimates of the challenges they face in teaching the values of citizenship that can be attributed to the gender variable. But there are differences attributed to specialization and is in favor of the specialization of geography. Therefore, the study recommends that the values of citizenship be given more attention in the curriculum by training teachers in the context of teaching based on classroom activities.

Keywords: Teaching Citizenship, Basic Schools, Clients, Challenges. 


\section{Introduction}

Values play an important and fundamental role in human life. They are oriented to their behavior, organized to their wishes, and to their needs. Generally speaking, when the values are becoming parts of everyday activities, they slowly acquired their legitimacy in society. Values are therefore necessary at both the individual and collective levels. The importance of values at the individual level is highlighted by the individual's keen need to deal with people, attitudes, and objects to a system of standards and values that serve as guidance to his behavior and activity. At the collective level, any social organization in need of a system of values stems from its objectives and ideals, on which its life, activities, and relations are based. It is internationally accepted that each society has its own value framework where the members of society are accustomed to (Fauzi, 2007).

The education of generations on the values of citizenship is the central goal of education. It means helping young people to understand reality and interact with its problems in a critical and objective way, thus giving them a positive attitude towards active participation. Therefore, the development of the values of citizenship carries more meaning than mere indoctrination; they are more towards the individual's duties, roles and responsibilities towards his society (Ibrahim, 2002).

Based on these concepts, stressing values is important of raising citizenship in the societies that want to progress and improve their life and creating mature people holding those values. The progress occurs only if the individuals are aware of their fate and their role in decision-making, enjoying a national character engrossed with values of love and loyalty and pride in belonging to the homeland and the realization of dimensional geographical, linguistic, historical and cultural background.

There are values that have a very important influence on the behavior of the members of society, including moral, social and political values with each of which contains a value that contributes to the citizenship concept. This mean the citizenship has its own values and similarly the political, social, economic and cultural -all have their own values. The teaching of these values is not confined to knowledge, instruction, religious preaching, or moral advice; it is rather a frame that contains the educational function with philosophy, policy, methods, practice, interaction and coexistence contexts in the school within its jurisdiction and powers (Qindeel, 2001).

The responsibility of education in the development of the values of citizenship appeared in two directions, complement to each other. The first is to provide and develop the values associated with citizenship, while the second trend is to build positive attitudes towards these values. The outcome of these two approaches is to build awareness of the values of citizenship among students and translate it into practical on daily practice. It should be mentioned that this is the responsibility of all institutions of formal and informal education, which require integration between the family, the school and all institutions of society (Musaa, 2005).

It is worth mentioning that schools play an important role in the development of the values of citizenship through creating a climate or an appropriate learning environment that encourages students to acquire these values. This role is determined by the teacher who should be a good role model for the students whose character resemble those values upon practicing actions surrounded by democracy, maintaining friendly relations with students, respecting them, and allowing them to express their views freely. Additionally, student activities also play an important role in promoting 
the values of citizenship through the spirit of cooperation, volunteerism, tolerance, justice, equality and participation. Prior to that, the role of courses and study plans in the development of the values of citizenship, with its knowledge content and attitudes that contribute significantly to this aspect.

In addition, the school has an important role in the educational system because its curricula having a direct impact on the development and socialization of young people and the consolidation of the values of citizenship and its effectiveness in achieving its objectives. Education reformers in Jordan have already recognized the importance of these curricula and the important role that they play. They have always been keen to develop them so as to always remain highly competent. They play an important role in developing the values of citizenship for the information they contain about political systems, national duties, as well as a set of values such as belonging to nation, loyalty to the homeland throughout consultation, coexistence with others, establishing social justice, and others relevant issues (Aleemaat, 2001).

There have been many manifestations of the lack of awareness of the development of citizenship in the society, which reflects the impact on individuals and subsequently formed a challenge to the teachers of social education at different stages. It is therefore necessary to pay attention to the education of young people and youth, and to pay more attention to citizenship education in the role of education in general in the development of the values of citizenship. It is only through systematic and organized plans of education as a weapon against the problems of non-adaptation, alienation and erosion of identity. The goal of all of them lies in the realization of an important educational principle: preparing the good citizen and effective citizenship (ElMerhaby, 2008).

In this regard, the teacher of these materials is the most prominent members of the educational institution, which ensures the implementation of the curriculum realistically and through the role of the teacher in the transfer of the values of the community and instilling and emphasize the cultural and civilizational elements in the request of the owners to build the social umbrella and associated with any change covered. These matters contribute effectively to overcoming the conflict between traditional and modern values. For all above reasons, this study revealed the challenges and difficulties faced by teachers of social materials in establishing the values of citizenship

\section{Problem Statement and Research Questions}

The problem of the study stems from the general feeling of many young people today of the weak relationship, citizenship, and social responsibility as presented in previous studies such as El-Merhaby (2008) and Fauzi (2007). It was noted that there is weakness and lack of practices in the principles of citizenship of some social studies teachers within the classroom. The teachers themselves are seemingly appeared confused to a certain extent in defining the concept of the citizenship (Fauzi, 2007). Based on the above arguments, the present study sought to identify the most important problems and challenges facing social material teachers regarding the values of citizenship in all its political, social, cultural and other fields for the basic stage in Ajloun city by answering the following questions: 
1. What are the main challenges facing the teaching of the values of citizenship from the point of view of social studies teachers in Ajloun?

2. Are there statistically significant differences at the level of significance $(p \ll 0.05)$ in the responses of the sample members of the study due to gender variables and specialization?

\section{Research Objectives}

The study aims at identifying the challenges facing the teaching of the values of citizenship based on the point of view of the social studies teachers in Ajloun. It also aims to determine whether there are differences in the responses of the sample of the study according to gender and specialization.

\section{Significance of the Study}

This study is targeting the following institutions to acquire enough benefit from the study:

1. The Ministry of Education through the study of teaching problems in all its themes, and to reach the results that help to develop the competencies of the teachers of social educational materials related to the problems.

2. Supervisors of social materials in the field of education and specialists to provide them with a research tool to help identifying the educational problems facing teachers of social materials in the teaching of the values of citizenship.

3. It is hoped that this study will enrich the knowledge of research studies related to the problems facing teachers in general and social studies in particular and, in general, to the values of citizenship.

\section{Scope of the Study}

The scope of the current study is limited to the following constraints:

- Objective boundaries: knowledge of the most important challenges facing the teaching of the values of citizenship from the perspective of social studies teachers in the Ajloun, Jordan.

- Spatial boundaries: The study is limited to all the basic government schools in Ajloun, Jordan

- Human boundaries: The study is limited to all teachers of the eighth grade in schools in Ajloun, Jordan.

- Time Limits: This study is applied during the academic year 2018/2019. 
INTERNATIONAL JOURNAL OF ACADEMIC RESEARCH IN BUSINESS AND SOCIAL SCIENCES

Vol. 9, No. 6, June, 2019, E-ISSN: 2222-6990 @ 2019 HRMARS

\section{Terminology of study}

The following terms were adopted in this study to achieve the objectives:

\begin{tabular}{|c|c|c|}
\hline term & Meaning & Reference \\
\hline $\begin{array}{l}\text { Teaching } \\
\text { problems } \\
\text { (Methodological) }\end{array}$ & $\begin{array}{l}\text { Difficulties in terms of physical or moral obstacles that limit } \\
\text { the achievement of the educational objectives and cause } \\
\text { fatigue, anxiety and frustration for both teachers and } \\
\text { learners. }\end{array}$ & $\begin{array}{l}\text { (Rowaidaheh, } \\
\text { 2003) }\end{array}$ \\
\hline $\begin{array}{l}\text { Teaching } \\
\text { problems } \\
\text { (Procedural) }\end{array}$ & $\begin{array}{l}\text { Every obstacle facing the teachers of social materials and } \\
\text { affect their education and prevent them from achieving their } \\
\text { educational goals that they planned to complete and carry out }\end{array}$ & \\
\hline $\begin{array}{l}\text { The values of } \\
\text { citizenship } \\
\text { (Methodological) }\end{array}$ & $\begin{array}{l}\text { The set of values that reflect the student's belonging to his } \\
\text { country, political awareness, environmental, health, } \\
\text { economic, and human rights, openness to other cultures, the } \\
\text { need for law, belief in national unity, tolerance of others, and } \\
\text { social responsibility towards himself, his family and society }\end{array}$ & $\begin{array}{l}\text { Al-Rinteesy, } \\
\text { 2011) }\end{array}$ \\
\hline $\begin{array}{l}\text { Values } \\
\text { citizenship } \\
\text { (Procedural) }\end{array}$ & $\begin{array}{l}\text { A set of values that aim at preparing the student citizen who } \\
\text { is socially active with his peers in his environment and his } \\
\text { community environment and aware of the political values of } \\
\text { democracy and freedom of expression in relation to the } \\
\text { authorities and citizens of the state to which he belongs. }\end{array}$ & \\
\hline
\end{tabular}

\section{Previous Studies}

The followings are the most important previous studies related to the current study. The review is arranged into studies that focus on the difficulties faced by social studies teachers and, secondly, studies related to the national values included in the social studies curricula, arranged in chronological order from oldest to newest.

\section{Studies related to the difficulties faced by teachers of social studies}

In the study of Lazuras (2009) aimed at the detection of occupational stress, its negative impact, and the performance of social studies teachers in Greece. The study was applied to 50 teachers. The results showed that there are pressures caused by professionalism based on personal conflicts and workload, which negatively affect teachers' performance.

Th study of Talaf'hah (2013) revealed the level of work pressure of the social studies teachers in elementary stage of the public schools in Amman. The study also identifies the problems resulting that pressure. The other issue was about the knowledge of the impact of gender, experience and scientific qualification in their estimation of the level of these pressures. The study sample consists of (228) teachers distributed in four directorates of education in Amman. The most common problems experienced by teachers are (mental) fatigue and physical fatigue, and, to less extent, the inability to sleep. 
The other study performed by Al-Ma'mary, (2014) who sought identifying the obstacles faced by the social studies teachers from their point of view. Then, he identified the degree of difficulties faced by the teachers of social studies in post-primary education in the Sultanate of Oman. The study reveals that the effect of the factor gender and teaching experience. The sample for the areas of difficulty teaching social studies books at this stage. The study was applied to a sample of (96) teachers of the subjects of social studies in post-primary education in the public schools in the Sultanate of Oman. The study adopted the descriptive method by monitoring the phenomenon and collecting the data on the field by means of the questionnaire tool. The results showed that the difficulties related to the students are one of the most difficult issues affecting the teaching of social studies. In addition, the difficulties associated with the sources of learning and teaching methods, and the difficulty of employing methods of teaching

\section{Studies related to the national values included in the curricula of social studies}

Williams (2001) conducted a study aimed at exposing the values of human rights in the textbooks of social studies in secondary schools in Alberta, Canada. The author conducted a qualitative analysis of ten textbooks of social studies used in teaching. The most important results are that the contents of the textbooks do not serve the true spirit of students or teachers. Hence, he recommended that the textbooks be provided with additional sources on the concepts of the values of human rights education.

In the case study conducted by Marri (2005), she aimed to build a conceptual framework based on democratic education for multicultural classes under the experience of three skilled teachers in the social studies curriculum in the United States by answering the following two questions: the first question is about how to teach democracy to students with multiple cultures; and secondly, what are the barriers that teachers face in teaching democracy to multicultural students. The results of the study showed the effectiveness of democratic education in providing opportunities to help learning to find effective citizens by providing them with democratic concepts in their educational institutions.

The study conducted by Al-Jamal, A. (2007) aimed at identifying the effectiveness of a suggested unit in the history curriculum in the preparatory stage, including the values of citizenship in developing awareness of social responsibility and co-existence with the other in second grade students. The study prepared a list of citizenship values related to the history curriculum that included values of social responsibility, freedom, equality. The researcher then prepared a measure of awareness of the value of social responsibility and the value of coexistence with others. The study was based on a sample of 45 students. The study showed the effectiveness of the proposed unit based on the values of citizenship in developing awareness of social responsibility and coexistence with others.

In addition, Husain, A. (2009) conducted a study aimed at evaluating the objectives and content of the curricula of social studies (geography) in the preparatory stage in light of the values of citizenship. The researcher prepared a list of suitable citizenship values to determine their availability of the objectives and content of social studies curricula. The study of social studies in the preparatory stage includes the value of the greatness of the Creator and the value of loyalty to the country and its culture and traditions. The study also pointed to the reduction of observance of the objectives of 
the social studies curriculum for a number of values of citizenship such as justice, equality, respect for public property, the love of national unity, respect for law, preservation of the environment and non-violence. The study showed a clear failure to take account of the total content of the curriculum of social studies in the preparatory stage of the appropriate citizenship values for this stage.

In a review of the literature on citizenship education in secondary schools, Geboers et al. (2013) analyzed studies published in the period 2003-2009 related to citizenship education through a comprehensive survey of a set of databases. The results of the study showed that the open classroom environment in terms of discussion and collective dialogue has an effective impact on the development of citizenship values among school students. The study also showed that the curriculum, which includes projects and activities related to citizenship, is an important part in teaching the values of citizenship to students.

It is clear from the review of previous educational literature that there is a constant interest by researchers to identify the difficulties faced by social studies teachers, study their impact on achieving the objectives of the curriculum, and also study the values and extent of inclusion in the content of social textbooks. It is also apparent that there is no recent comprehensive study that focused on the difficulties faced by social studies teachers in teaching specific national values. Therefore, the current study seeks to fill this gap, especially at this stage, which is witnessing a trend towards building new curricula in the light of the standards in Jordan, which requires knowledge of these problems and make recommendations and proposals that may contribute to reducing them.

\section{Methodology and procedures of the study}

- Study Approach: The study adopted the descriptive method used to describe the phenomenon, because it is the most suitable method for the current study which seeks to identify the challenges facing the teaching of the values of citizenship based on the of the view of social studies teachers.

- Study Population: The population consists of all of the 177 teachers (males and females) of the basic stage in the public schools affiliated to the Directorate of Education for the governorate of Ajloun.

- Sampling: A sample of (150) teachers (males and females) was selected from the study population in the simple random way. The questionnaire was distributed to them. After collecting the questionnaires, the number of retrieved was 56 . Thus, the study sample reached (94) teachers.

- Instrumentation: The instrumentation was developed based on previous studies. The questionnaire consists of (40) items. The response is categorized based on Likert-5-scale model as follows: agree very strongly (5 points), agree strongly (4 points), agree moderately ( 3 points), agree slightly ( 2 points), and agree very low (1 point). The following assessment procedure is used for the purposes of the study instrument: The upper limit of the alternatives is (5), the minimum limit of alternatives is (1). The arithmetic mean (average) is calculated by 
subtracting the lower limit (1) from the upper limit of (5) and dividing the difference between the two levels by 3 as shown in the following equation:

$$
\text { Arithmatic Average }=\frac{\text { Upper Limit }- \text { Lower Limit }}{3}=\frac{5-1}{3}=1.33
$$

The average of standard deviation is calculated as follows:

$$
\operatorname{Avg} \cdot \operatorname{Std} \cdot \operatorname{Dev} \cdot\left(\sigma_{\text {avg }}\right)=\frac{\sqrt{\sum_{i=1}^{n} \sigma_{n}^{2}}}{n}
$$

Thus, the degree of each item in the questionnaire is assessed according to data in Table 1.

\begin{tabular}{|c|c|c|}
\hline \multicolumn{2}{|c|}{ Limit of Arithmetic Mean } & \multirow{2}{*}{ Degree } \\
\hline Lower Limit & Upper Limit & \\
\hline 1.00 & 2.33 & Low \\
\hline 2.34 & 3.67 & Medium \\
\hline 3.68 & 5.00 & High \\
\hline
\end{tabular}

Table 1. Assessment of the degree of arithmetic mean

- Validation: The validation was initially presented to (5) specialized arbitrators and asked them to determine the appropriateness of the questions in regard to clarity, linguistic integrity, suggestions to any proposed amendments, propose deleting any unnecessary statement, and delete unnecessary statement. The standard of agreement (80\%) was approved by the arbitrators' committee to be amended, deleted and added. After the tool was reintroduced, the proposed amendments were made by the arbitrators using their recommendations.

- Stability: Stability is the accuracy and consistency of individual performance over time. The constant test yields the same results if applied to the same group of individuals again. The Cronbach's Alpha is calculated for internal consistency. The result is statistically acceptable if its value is greater (0.60). The internal consistency coefficient of the questionnaire as a whole is 0.79. Therefore, the data obtained are suitable for measuring the variables and are subjected to a high degree of reliability.

\section{- Variables}

O Independent variables: the prediction of social studies teachers in the basic stage on the paragraphs of the study tool.

o Intermediate variables:

- Gender has two categories (male and female).

- Specialization has three categories (history, geography, and social education).

- Dependent variables: represented by the challenges faced by social studies teachers in teaching the values of citizenship. 
- Procedure of the study: The procedure of the study is performed as follows:

o Collect the theoretical literature of the study by reviewing sources and references.

- Description of the population and sampling and the study tool and the necessary statistical treatments.

- Preparation of the study tool, and the extraction of the signs of honesty and persistence.

- Application of the study tool on the sample of the study of teachers and teachers of the basic stage in the private schools of the Directorate of Education of Ajloun Governorate. The distribution of the tool took 3 weeks.

- After the distribution was completed and the copies were collected, the data was tabulated on special lists, then the data was entered into the computer and processed statistically using the SPSS program.

○ Explain the results, discuss them and make recommendations.

\section{Results}

The followings are the findings each question of the study:

Question 1: What are the most important challenges facing the teaching of the values of citizenship from the point of view of social studies teachers in Ajloun?

The average and standard deviation of the following seven fields: objectives, teaching methods and activities, methods of teaching and presentation of content, use of learning resources, managing class and class interaction, developing skills, values and trends, and evaluation of the trend as shown in Table 2 through Table 8, respectively.

- (1) The field of objectives

In this field, there are four items as shown in Table 2 which is also contains the analysis of these items. Table 2. Results of the field of objectives

\begin{tabular}{llcccc}
\hline $\begin{array}{c}\text { Item } \\
\#\end{array}$ & \multicolumn{1}{c}{ Item Details } & $\begin{array}{c}\text { Arithmetic } \\
\text { Mean }\end{array}$ & $\begin{array}{c}\text { Standard } \\
\text { Deviation }\end{array}$ & Rank & Degree \\
\hline $3 \quad \begin{array}{l}\text { The inability to diversify levels of } \\
\text { cognitive, skills and emotional goals. }\end{array}$ & 2.81 & 0.51 & 1 & Medium \\
$4 \quad \begin{array}{l}\text { Difficulty of formulating objectives to } \\
\text { include all aspects of values and } \\
\text { educational learning attitude. }\end{array}$ & 2.69 & 0.61 & 2 & Medium \\
$2 \quad \begin{array}{l}\text { I feel that I cannot formulate } \\
\text { behavioral goals in the lessons related } \\
\text { to citizenship. }\end{array}$ & 2.43 & 0.82 & 3 & Medium \\
& $\begin{array}{l}\text { Difficulty of clarifying the objectives } \\
\text { of lessons related to national values } \\
\text { at the beginning of the classroom. }\end{array}$ & 2.33 & 0.59 & 4 & Low \\
\hline Average & & & & & \\
\hline
\end{tabular}


INTERNATIONAL JOURNAL OF ACADEMIC RESEARCH IN BUSINESS AND SOCIAL SCIENCES

Vol. 9, No. 6, June, 2019, E-ISSN: 2222-6990 @ 2019 HRMARS

It is clear from the results in Table (2) that the total score of the field of objectives is medium with a mean of 2.56 and a standard deviation of 0.32 . Item (3) is assessed at medium with arithmetic mean of 2.81 and standard deviation of 0.51 . Item (1) is assessed at Low with arithmetic mean of 2.33 and standard deviation of 0.73 .

- (2) The field of educational means and activities

There are four items as shown in Table 3 which is also contains the analysis of these items.

Table 3. The field of educational means and activities

\begin{tabular}{llcccc}
\hline $\begin{array}{c}\text { Item Item Details } \\
\#\end{array}$ & $\begin{array}{c}\text { Arithmetic } \\
\text { Mean }\end{array}$ & $\begin{array}{c}\text { Standard } \\
\text { Deviation }\end{array}$ & Rank & Degree \\
\hline $8 \quad \begin{array}{l}\text { Difficulty of focusing on applied } \\
\text { activities rather than theoretical } \\
\text { activities. }\end{array}$ & 4.06 & 0.89 & 1 & High \\
$7 \quad \begin{array}{l}\text { No use of classroom activities that } \\
\text { interest students and encourage them } \\
\text { to cooperate. }\end{array}$ & 3.52 & 0.96 & 2 & Medium \\
$5 \quad \begin{array}{l}\text { I feel unable to organize students' } \\
\text { participation in the use of teaching } \\
\text { aids in the educational learning } \\
\text { situation. }\end{array}$ & & 0.52 & 3 & Medium \\
Difficulty of determining the goal of \\
the educational activity before starting \\
it.
\end{tabular}

Table (3) shows the estimates of the sample members of the field of means and educational activities. It is clear that the total score of the sample estimates on the subjects of this sample showing medium order with mean of 3.23 and standard deviation of 0.43 . Item (8) is high with arithmetic average of 4.06 and standard deviation of 0.89 . Item 6 is medium with arithmetic mean of 2.64 and standard deviation of 0.97 .

- (3) The field of teaching methods and presentation of content

There are six items along with their statements, arithmetic mean, standard deviation, rank, and order as depicted in Table 4. 
INTERNATIONAL JOURNAL OF ACADEMIC RESEARCH IN BUSINESS AND SOCIAL SCIENCES Vol. 9, No. 6, June, 2019, E-ISSN: 2222-6990 @ 2019 HRMARS

Table 4. The field of teaching methods and presentation of content

\begin{tabular}{|c|c|c|c|c|c|}
\hline $\begin{array}{c}\text { Item } \\
\#\end{array}$ & Item Details & $\begin{array}{l}\text { Arithmetic } \\
\text { Mean }\end{array}$ & $\begin{array}{l}\text { Standard } \\
\text { Deviation }\end{array}$ & Rank & Degree \\
\hline 11 & $\begin{array}{l}\text { The difficulty of diversification in the } \\
\text { teaching methods used in the } \\
\text { educational condition. }\end{array}$ & 3.75 & 0.77 & 1 & High \\
\hline 12 & $\begin{array}{l}\text { I find it difficult to use the method of } \\
\text { problem solving and develop the } \\
\text { scientific method for students. }\end{array}$ & 3.63 & 0.93 & 2 & Medium \\
\hline 14 & $\begin{array}{l}\text { The inability to use the role play } \\
\text { method when presenting important } \\
\text { local and national characters. }\end{array}$ & 3.35 & 0.88 & 3 & Medium \\
\hline 13 & $\begin{array}{l}\text { Difficulty of determining the goal of the } \\
\text { educational activity before starting it. }\end{array}$ & 3.23 & 0.87 & 4 & Medium \\
\hline 9 & $\begin{array}{l}\text { Difficulty providing the opportunity for } \\
\text { student participation through open } \\
\text { discussion. }\end{array}$ & 2.68 & 0.57 & 5 & Medium \\
\hline 10 & $\begin{array}{l}\text { Difficulty providing the opportunity for } \\
\text { student participation through open } \\
\text { discussion. }\end{array}$ & 2.07 & 0.69 & 6 & Low \\
\hline \multicolumn{2}{|c|}{ Average } & 3.11 & 0.39 & - & Medium \\
\hline
\end{tabular}

Table (4) shows the estimates of the sample of the study sample for the fields of teaching methods and presentation of the content. The total score of the sample estimates for the subjects in this field is averaged at 3.11 and standard deviation of 0.39. Item (11) scored high with arithmetic mean of 3.75 and standard deviation of 0.77. Item (10) scored low with arithmetic average of 2.07 and standard deviation of 6.90 . 
INTERNATIONAL JOURNAL OF ACADEMIC RESEARCH IN BUSINESS AND SOCIAL SCIENCES

Vol. 9, No. 6, June, 2019, E-ISSN: 2222-6990 @ 2019 HRMARS

- (4) The field of use of learning resources

There are only two items in this field. Table 5 shows the items and their corresponding arithmetic mean, standard deviation, rank, and order.

Table 5. The field of use of learning resources

\begin{tabular}{clcccc}
\hline $\begin{array}{c}\text { Item } \\
\#\end{array}$ & \multicolumn{1}{c}{ Item Details } & $\begin{array}{c}\text { Arithmetic } \\
\text { Mean }\end{array}$ & $\begin{array}{c}\text { Standard } \\
\text { Deviation }\end{array}$ & Rank & Degree \\
\hline 15 & $\begin{array}{l}\text { Difficulty employing the Internet in } \\
\text { teaching and learning citizenship } \\
\text { lessons. }\end{array}$ & 3.96 & 0.85 & 1 & High \\
$16 \quad \begin{array}{l}\text { The difficulty of being able to employ } \\
\text { ongoing national events as a source of } \\
\text { learning within the classroom. }\end{array}$ & 2.42 & 0.0 .52 & 2 & Medium
\end{tabular}

\begin{tabular}{lllll}
\hline Average & 3.18 & 0.79 & - & Medium
\end{tabular}

Table (5) shows the estimates of the sample of the study sample for the fields of learning resource use. It is clear that the total score of the sample estimates for the subjects in this field is average of 3.18 and standard deviation of 0.79 . Item 15 records high with arithmetic mean of 3.96 and standard deviation of 0.85 , followed by item 16 arithmetic mean of 3.18 and standard deviation of 0.79 .

- (5) Class management and class interaction

There are nine items in this field. Table 6 shows the items and their corresponding arithmetic mean, standard deviation, rank, and order.

Table 6 . The field of Class management and class interaction

\begin{tabular}{|c|c|c|c|c|c|}
\hline $\begin{array}{l}\text { Item } \\
\#\end{array}$ & Item Details & $\begin{array}{l}\text { Arith } \\
\text { meti } \\
\text { c } \\
\text { Mea } \\
\mathrm{n}\end{array}$ & $\begin{array}{l}\text { Standard } \\
\text { Deviation }\end{array}$ & Rank & Degree \\
\hline 17 & $\begin{array}{l}\text { I suffer from increasing numbers } \\
\text { of students in the classroom. }\end{array}$ & 4.02 & 0.91 & 1 & High \\
\hline 24 & $\begin{array}{l}\text { The difficulty of engaging } \\
\text { students in assuming leadership } \\
\text { responsibilities within the } \\
\text { classroom. }\end{array}$ & 4.01 & 0.84 & 2 & Medium \\
\hline 25 & $\begin{array}{l}\text { Difficult to follow a variety of } \\
\text { procedures to deal with } \\
\text { individual differences and to } \\
\text { address students' learning }\end{array}$ & 3.22 & 0.83 & 3 & Medium \\
\hline
\end{tabular}


difficulties while achieving national goals.

18 The difficulty of leading the

$2.83 \quad 0.52 \quad 4 \quad$ Medium classroom towards achieving the educational goals skillfully and efficiently.

23 The difficulty of developing

$\begin{array}{llll}2.76 & 0.48 & 5 & \text { Medium }\end{array}$ internal intelligence to maintain order and values.

22 I do not allow freedom of opinion

$2.72 \quad 0.45 \quad 6 \quad$ Medium and expression in a democratic manner.

19 Weak ability to encourage

$\begin{array}{llll}2.70 & 0.46 & 7 & \text { Medium }\end{array}$
students and encourage them to participate actively.

21 Difficult interaction between $2.29 \quad 0.88 \quad 8 \quad$ Low students themselves.

20 Difficult interaction between the $\begin{array}{llll}2.04 & 0.61 & 9 & \text { Low }\end{array}$ teacher and students.

\begin{tabular}{lllll}
\hline Average & 2.96 & 0.20 & - & Medium \\
\hline
\end{tabular}

Table (6) shows the estimates of the sample members for the fields of classroom management and class interaction. It is clear that the total score of the sample estimates for the subjects in this field was average of 2.96 and standard deviation of 0.20 . Item (17) shows the first order high of arithmetic average of 4.02 and standard deviation of 0.91. Item (20) is low with a mean of 2.04 and standard deviation of 0.66 . 
INTERNATIONAL JOURNAL OF ACADEMIC RESEARCH IN BUSINESS AND SOCIAL SCIENCES

Vol. 9, No. 6, June, 2019, E-ISSN: 2222-6990 @ 2019 HRMARS

- (6) Development of skills, values and trends

There are seven items in this field. Table 7 shows the items and their corresponding arithmetic mean, standard deviation, rank, and order.

Table 7. The field of Development of skills, values and trends

\begin{tabular}{|c|c|c|c|c|c|}
\hline $\begin{array}{c}\text { Item } \\
\#\end{array}$ & Item Details & $\begin{array}{l}\text { Arithmetic } \\
\text { Mean }\end{array}$ & $\begin{array}{l}\text { Standard } \\
\text { Deviation }\end{array}$ & Rank & Degree \\
\hline 27 & $\begin{array}{l}\text { The difficulty of providing an educational } \\
\text { condition that contributes to the } \\
\text { development of religious awareness and } \\
\text { awareness among students. }\end{array}$ & 3.75 & 0.91 & 1 & High \\
\hline 29 & $\begin{array}{l}\text { I feel unable to develop the skill of } \\
\text { criticism and scrutiny in receiving } \\
\text { information and adopting ideas from } \\
\text { different sources. }\end{array}$ & 3.47 & 0.84 & 2 & Medium \\
\hline 32 & $\begin{array}{l}\text { I find it difficult to accustom students to } \\
\text { conduct and adhere to democratic } \\
\text { principles. }\end{array}$ & 2.47 & 0.92 & 3 & Medium \\
\hline 26 & $\begin{array}{l}\text { Difficult to train students to make } \\
\text { rational decisions about their daily lives. }\end{array}$ & 3.17 & 0.87 & 4 & Medium \\
\hline 28 & $\begin{array}{l}\text { The difficulty of the ability to develop } \\
\text { national and national affiliation through } \\
\text { the lesson material. }\end{array}$ & 2.80 & 0.75 & 5 & Medium \\
\hline 30 & $\begin{array}{l}\text { I have a problem in developing the } \\
\text { practical skills and competencies } \\
\text { required for effective citizenship. }\end{array}$ & 2.25 & 0.87 & 6 & Medium \\
\hline 31 & $\begin{array}{l}\text { I feel unable to develop attitudes that } \\
\text { enable students to contribute positively } \\
\text { to human relations such as (freedom of } \\
\text { expression, cooperation, respect for } \\
\text { others). }\end{array}$ & 2.41 & 0.78 & 7 & Medium \\
\hline
\end{tabular}

Average

2.95

0.20

Medium

Table (7) shows the estimates of the sample members for the skills development, values and trends. It is clear that the total score of the sample estimates for the subjects in this field is medium with an average of 2.95 and standard deviation of 0.20 . Item (27) is scored high with arithmetic average of 
INTERNATIONAL JOURNAL OF ACADEMIC RESEARCH IN BUSINESS AND SOCIAL SCIENCES

Vol. 9, No. 6, June, 2019, E-ISSN: 2222-6990 @ 2019 HRMARS

3.75 and standard deviation of 0.92 . Item (31) is medium mean of 2.41 and standard deviation of 0.78 .

- (7) The field of evaluation methods

There are three items in this field. Table 8 shows the items and their corresponding arithmetic mean, standard deviation, rank, and order.

Table 8. The field of The field of evaluation methods

\begin{tabular}{clcccc}
\hline $\begin{array}{c}\text { Item } \\
\#\end{array}$ & \multicolumn{1}{c}{ Item Details } & $\begin{array}{c}\text { Arithmetic } \\
\text { Mean }\end{array}$ & $\begin{array}{c}\text { Standard } \\
\text { Deviation }\end{array}$ & Rank & Degree \\
\hline 35 & $\begin{array}{l}\text { Difficult to take pre-exams to learn } \\
\text { about students' preparations and } \\
\text { levels. }\end{array}$ & 4.11 & 0.89 & 1 & High \\
$33 \quad$ I find it difficult to vary in the \\
assessment tests (written, oral, \\
practical) to see how well the lesson \\
objectives related to values are \\
achieved.
\end{tabular}

\begin{tabular}{lllll}
\hline Average & 3.02 & 0.58 & - & Medium \\
\hline
\end{tabular}

Table (8) shows the estimates of the sample members for the fields of evaluation methods. It is clear that the total score of the sample estimates for the subjects in this field is medium with average of 3.02 and standard deviation of 0.58. Item (35) is high rank with arithmetic mean of 4.11 and standard deviation of 0.89 . Item (34) score medium with mean of 2.37 and standard deviation of 0.87 .

The results of the second question, "Are there statistically significant differences at the level of significance $(p \leq 0.05)$ in the estimates of the study sample members in regard to the challenges facing the teaching of the values of citizenship by the teachers of social studies in Ajloun due to the variables of sex and specialization?

This question was answered according to each variable in the following order:

- First: The variable of the sex (male or female)

The arithmetic mean of the responding answers and their standard deviation were calculated to identify the challenges to the teaching of citizenship values by social studies teachers attributed to the sex variable, and the t-test was used for two independent samples. The results are shown in Table (9). 
INTERNATIONAL JOURNAL OF ACADEMIC RESEARCH IN BUSINESS AND SOCIAL SCIENCES Vol. 9, No. 6, June, 2019, E-ISSN: 2222-6990 @ 2019 HRMARS

Table 9. Differences in the challenges faced by social studies teachers in teaching the values of citizenship according to the variable of gender

\begin{tabular}{lcccccc}
\hline Sex & Number & $\begin{array}{c}\text { Arithmetic } \\
\text { Mean }\end{array}$ & $\begin{array}{c}\text { Standard } \\
\text { deviation }\end{array}$ & t-test & $\begin{array}{c}\text { Degree of } \\
\text { Freedom }\end{array}$ & Significant \\
\hline Male & 40 & $3 / 01$ & 0.24 & 0.156 & 92 & 0.877 \\
Female & 54 & 3.02 & 0.25 & & & \\
\hline
\end{tabular}

Significant $p \leq 0.05$

Table (9) shows that there are no statistically significant differences ( $p=0.877$ ) between the arithmetical averages of the respondents' estimates of the challenges faced by the social studies teachers in teaching the values of citizenship according to variable of gender.

- Variable of Specialization (history, geography, etc.)

The arithmetical averages and the standard deviations of the sample estimates were calculated for the challenges faced by social studies teachers in teaching the values of citizenship according to the specialization variable. The results are shown in Table (10).

Table 10. Mathematical averages and standard deviations of the challenges facing the teaching of the values of citizenship by the teachers of social studies according to the variable of specialization

\begin{tabular}{lccc}
\hline Specialization & Number & Arithmetic Mean & Standard Deviation \\
\hline History & 30 & 2.67 & 0.26 \\
Geography & 25 & 2.68 & 0.33 \\
Social Studies & 39 & 2.41 & 0.29 \\
Total & 94 & 2.02 & 0.24 \\
\hline
\end{tabular}

The results in Table (10) show that there are apparent differences in the values of the arithmetical averages of the challenges faced by social studies teachers in teaching the values of citizenship according to the specialization variable. In order to determine whether these differences are statistically significant, a single variance analysis was performed. The results are shown in Table (11).

Table 11. Results of the analysis of the variance of the effects of specialization on the challenges faced by social studies teachers in teaching the values of citizenship

\begin{tabular}{lccccc}
\hline Type & $\begin{array}{c}\text { Sum of } \\
\text { squares }\end{array}$ & $\begin{array}{c}\text { Degree of } \\
\text { Freedom }\end{array}$ & $\begin{array}{c}\text { Mean of } \\
\text { Squares }\end{array}$ & F-value & Significant \\
\hline Between Groups & 4.006 & 2 & 2.003 & 131.380 & $\ll 0.05$ \\
Inside Groups & 1.377 & 91 & 0.015 & & \\
\hline Total & 5.383 & 93 & & & \\
\hline
\end{tabular}

Table (11) shows statistically significant differences between the arithmetic averages of respondents' estimates of the challenges faced by social studies teachers in teaching citizenship values. In order to identify the variance of differences, use the Scheffe test for post-comparisons. The results are shown in Table 12. 
INTERNATIONAL JOURNAL OF ACADEMIC RESEARCH IN BUSINESS AND SOCIAL SCIENCES Vol. 9, No. 6, June, 2019, E-ISSN: 2222-6990 @ 2019 HRMARS

Table 12. The results of the Schiffe test for distance comparisons between teachers' estimates of the challenges of teaching citizenship values according to the specialization variable

\begin{tabular}{lcc}
\hline Specialization & Geography (3.36) & Significant \\
\hline History (2.93) & 0.433 & $\ll 0.05$ \\
Social Studies (2.87) & 0.488 & $\ll 0.05$ \\
\hline
\end{tabular}

Bases on Significant $p \leq 0.05$

The results in Table (12) indicate that the differences between the estimates of the sample of the challenges facing the teaching of the values of citizenship according to the specialization variable came between the specialization of geography and history on the one hand and in favor of the specialization of geography and the specialization of geography and social education.

\section{Discussion}

- First: To discuss the results of the first question: "What are the most important challenges facing the teaching of the values of citizenship from the point of view of social studies teachers in Ajloun?"

The results show that social studies teachers in Ajloun face many challenges in teaching the values of citizenship in different areas such as goals, methods and educational activities, teaching methods and presentation of content, use of learning resources, classroom management and classroom interaction, skills development, values and trends, and means of correctness.

The results showed, in particular, that teachers face challenges related to the inability to diversify their levels to cover cognitive, skill, and emotional goals. They also face other challenges, such as the difficulty of formulating objectives to include all values and educational learning attitude, and the inability to formulate behavioral goals in the teaching of citizenship.

In the field of educational means and activities, the results showed that the most challenging challenges faced by teachers are those related to the difficulty of focusing on applied activities rather than the theoretical activities, the non-use of classroom activities that interest students and encourage them to cooperate, Organizing the participation of students in the use of educational aids in the learning educational situation. These results were consistent with a number of findings from a previous study, such as Geboers et al., 2013, which emphasized the importance of classroom projects and activities that promote students' citizenship values.

In the use of learning resources, it became clear that the most important challenge is the difficulty of employing the Internet in teaching and learning citizenship lessons. In terms of classroom management and class interaction, the most common challenge among teachers is the increasing number of students in the classroom, followed by the difficulty of achieving student participation in leadership responsibilities within classrooms. Finally, in the context of assessment methods, the most important challenge for teachers was the difficulty of conducting pre-exams in order to identify students' preparations and levels.

- Second: The results of the second question were discussed, "Are there statistically significant differences at the level of significance $(p \leq 0.05)$ in the estimates of the study sample members in the challenges facing the teaching of the values of citizenship by the social studies teachers in Ajloun city due to gender variables, and specialization? " 
The results showed that there were no statistically significant differences between the respondents' estimates of the challenges faced by social studies teachers in teaching the values of citizenship according to the gender. But there are differences of statistical significance attributed to the teacher's specialization (history, geography, or social education) in favor of the specialization of geography.

\section{Recommendations}

In light of the results of the study, the researcher recommends that the worker should achieve the following:

$>$ Participation between schools and educational institutions to equip pre-service teachers with the necessary knowledge and skills to teach citizenship.

$>$ Training teachers to learn how to explain the objectives of lessons related to national values at the beginning of classroom classes.

$>$ Improve the level of mutual interaction between the students themselves and the teacher and students. 
INTERNATIONAL JOURNAL OF ACADEMIC RESEARCH IN BUSINESS AND SOCIAL SCIENCES

Vol. 9, No. 6, June, 2019, E-ISSN: 2222-6990 @ 2019 HRMARS

\section{References}

Alemaat, S. N. (2001). The role of national education in promoting citizenship, Jordan.

Al-Jamal, A. (2007). The effectiveness of a suggested unit in the Islamic history curriculum in the preparatory stage based on the values of citizenship in developing awareness of social responsibility and coexistence with the other in the second-grade preparatory students, Journal of the Educational Society for Social Studies. Journal of Educational Society, 12.

Al-Ma'maary, S. N. (2014). Degree of difficulties faced by post-primary education teachers in the Sultanate of Oman. The future of Arab education 17.

Al-Marhaby, S. N. (2008). Factors Affecting the Values of Citizenship among Secondary School Students in Amran Governorate, Unpublished Master Thesis, Republic of Yemen, Sanaa University.

Al-Rowaideh, S. M. (2003). Obstacles to the use of modern methods to teach the subjects of social studies at the basic education stage in Jordan. Journal of Educational Research, University of Qatar.

Al-Sharqaawy, M. A. (2005). University students' awareness of some of the values of citizenship "Field study", Journal of Studies in University Education, Center for the development of university education, Ain Shams University, p 114.

Fauzi, S. (2007). The Citizenship. First Edition, Cairo Center for Human Rights Studies, Cairo.

Geboers, E., Geijsel, F., Admiraal, W. and ten Dam, G. (2013). Review of the effects of citizenship education. Educational Research Review, 9, 158-173.

Husain, A. (2009), Evaluation of the objectives and content of the curricula of social studies in the preparatory stage in light of the values of citizenship, Journal of the Educational Association for Social Studies (1).

Lazuras, I. (2009). Occupational stress, negativity and physical health in and general education teacher in Greece. British journal of special education. 33(4):204-209.

Marri, A. (2005). Building a F framework For Classroom - Based Multicultural Democratic Education: Learning from Three Skilled Teachers, Teachers College Record, 107(5), 1036.

Murtajaa, Z. and Al-Riteesy. (2011). Evaluation of the content of curricula of civic education for the seventh, eighth and ninth grades in light of the values of citizenship, Journal of the Islamic University, 19(2).

Nasser, A. (2002). The Citizenship, First Edition.

Qindeel, Y. A. and mandoor, F. (2001). The effectiveness of using some of the entries of value education to provide topics related to issues of science, technology and society in the development of educational achievement and the values of citizenship of students in the first grade preparatory. Research presented to the Fifth Scientific Conference "Scientific Education of Citizenship. College of Education, Ain Shams University, Egypt

Talaf'hah, H. A. (2013). Work pressure at teachers of the basic stage in Jordan and the problems resulting from it. Journal of Islamic Sciences for Educational and Psychological Studies 21(1).

Williams, B. (2001). Alberta social studies textbooks and human rights educations. University Alberta, Canada. ERIC. 